\title{
Heterotopic Neurons with Altered Inhibitory Synaptic Function in an Animal Model of Malformation-Associated Epilepsy
}

\author{
Maria Elisa Calcagnotto, Mercedes F. Paredes, and Scott C. Baraban \\ Epilepsy Research Laboratory, Department of Neurological Surgery and The Graduate Program in Neuroscience, \\ University of California, San Francisco, San Francisco, California 94143
}

Children with brain malformations often exhibit an intractable form of epilepsy. Although alterations in cellular physiology and abnormal histology associated with brain malformations has been studied extensively, synaptic function in malformed brain regions remains poorly understood. We used an animal model, rats exposed to methylazoxymethanol (MAM) in utero, featuring loss of lamination and distinct nodular heterotopia to examine inhibitory synaptic function in the malformed brain. Previous in vitro and in vivo studies demonstrated an enhanced susceptibility to seizure activity and neuronal hyperexcitability in these animals. Here we demonstrate that inhibitory synaptic function is enhanced in rats exposed to MAM in utero. Using in vitro hippocampal slices and whole-cell voltage-clamp recordings from visualized neurons, we observed a dramatic prolongation of GABAergic IPSCs onto heterotopic neurons. Spontaneous

Epileptic seizures associated with a brain malformation are frequently severe and resistant to conventional anticonvulsant drugs. Often, surgical removal of abnormally organized tissue is the only effective form of seizure control for these early-onset epilepsies (Palmini et al., 1991b, 1995). With recent developments in brain imaging techniques, malformations have been identified in $\sim 30 \%$ of all new epilepsy cases (Kuzniecky, 1988; Palmini et al., 1991a; Mischel et al., 1995; Chan et al., 1998). Considerable evidence now suggests that malformed brain regions are a source of hyperexcitability and seizure genesis (Avoli et al., 1999; Maehara et al., 1999; Morioka et al., 1999; Andermann, 2000; Baraban et al., 2000; Ohtsuka et al., 2000); however, synaptic function in the dysplastic brain remains poorly understood.

Brain malformations are found not only in neocortical structures but also in the hippocampal formation (Houser, 1990; Hirabayashi et al., 1993; Raymond et al., 1994, Lehericy et al., 1995). These hippocampal malformations, which include microdysgenesis, granule cell dispersion, and nodular heterotopia, are especially intriguing given that the hippocampus is implicated in temporal lobe epilepsy (Schwartzkroin, 1994). To study the functional and molecular properties of dysplastic neurons, a number

Received Jan. 9, 2002; revised May 23, 2002; accepted June 6, 2002.

This work was supported by funds from the Sandler Family Supporting Foundation, March of Dimes, Parents Against Childhood Epilepsy, and National Institutes of Health (to S.C.B.). We thank Edward Cooper and members of the Baraban laboratory for comments on earlier versions of this manuscript, Peter Castro for expert technical assistance, and Anil Baghri and Samuel Pleasure for help with immunohistochemical protocols.

Correspondence should be addressed to S. C. Baraban, Box 0520, Department of Neurological Surgery, University of California, San Francisco, 513 Parnassus Avenue, San Francisco, CA 94143. E-mail: baraban@itsa.ucsf.edu.

Copyright (C) 2002 Society for Neuroscience $0270-6474 / 02 / 227596-10 \$ 15.00 / 0$
IPSC decay time constants were increased by $195 \%$ and evoked IPSC decay time constants by $220 \%$ compared with age-matched control CA1 pyramidal cells; no change in IPSC amplitude or rise time was observed. GABA transport inhibitors (tiagabine and NO-711) prolonged evoked IPSC decay kinetics of control CA1 pyramidal cells (or normotopic cells) but had no effect on heterotopic neurons. Immunohistochemical staining for GABA transporters (GAT-1 and GAT-3) revealed a low level of expression in heterotopic cell regions, suggesting a reduced ability for GABA reuptake at these synapses. Together, our data demonstrate that GABA-mediated synaptic function at heterotopic synapses is altered and suggests that inhibitory systems are enhanced in the malformed brain.

Key words: dysplasia; epilepsy; heterotopia; inhibition; GAT; patch clamp

of animal models have been developed that feature hippocampal dysgenesis. These include rats exposed to irradiation or methylazoxymethanol (MAM) in utero (Hicks et al., 1959; Baraban and Schwartzkroin, 1995), Lis1 and p35 knock-out mice (Fleck et al., 2000; Wenzel et al., 2001) and Ihara rats (Amano et al., 1996). In each of these animal models, spontaneous seizures or an increased susceptibility to convulsant agents has been reported.

Here we focused on rats exposed to MAM in utero because they are highly seizure susceptible (de Feo et al., 1995; Baraban and Schwartzkroin, 1996; Germano et al., 1996; Chevassus-auLouis et al., 1998a) and share many anatomical similarities with human malformation-associated epilepsies (Spreafico et al., 1998; Colacitti et al., 1999). Although heterotopic neurons in the MAM model lack Kv4.2 A-type potassium channels and exhibit "burster" firing properties (Sancini et al., 1998; Castro et al., 2001), there is no evidence of either spontaneous epileptic seizures in vivo or independent burst generation in vitro. Nodular heterotopia receive abundant GABAergic innervation in MAM-exposed rats (Baraban et al., 2000) and humans with cortical dysplasia (Spreafico et al., 2000), perhaps serving to dampen the intrinsic hyperexcitability associated with these regions or suppress spontaneous seizures. At present, the functional consequences of inhibitory inputs to heterotopic neurons have not been studied in great detail. To study GABAergic inhibition in the dysplastic MAMexposed rat brain, we examined the kinetic properties of evoked and spontaneous IPSCs onto individual heterotopic cells, physiological responses to exogenously applied GABA, and GABA transporter (GAT) expression. Here we present evidence for a significant alteration in inhibitory synaptic function at heterotopic synapses in MAM-exposed rats. 


\section{MATERIALS AND METHODS}

Prenatal methylazoxymethanol injection. Pregnant Sprague Dawley rats were injected with either $0.9 \%$ physiological saline (control) or $25 \mathrm{mg} / \mathrm{kg}$ MAM. MAM was purchased from NCI Chemical Carcinogen (Kansas City, MO). Intraperitoneal injections $(0.3 \mathrm{ml}, 15 \%$ DMSO) were made on embryonic day 15. All animal care and use conformed to the $N I H$ Guide for Care and Use of Laboratory Animals and were approved by the University of California, San Francisco Committee on Animal Research.

Hippocampal slice preparation. Acute tissue slices were prepared from male or female Sprague Dawley rat pups [postnatal day 14 (P14) to P25]. Briefly, the rats were decapitated, and the brain was rapidly removed in ice-cold oxygenated slicing medium, an artificial CSF (ACSF) consisting of (in mM): 220 sucrose, $3 \mathrm{KCl}, 1.25 \mathrm{NaH}_{2} \mathrm{PO}_{4}, 2 \mathrm{MgSO}_{4}, 26 \mathrm{NaHCO}_{3}$, $2 \mathrm{CaCl}_{2}$, and 10 dextrose (295-305 mOsm). A hemisphere of brain containing the hippocampus was blocked and glued (cyanoacrylic adhesive) to the stage of a vibroslicer [model NVSLM1 (Campden Instruments, Lafayette, IN) or model VTS1000 (Leica, Nussloch, Germany)]. Parasaggital hippocampal or coronal cortical (300- $\mu \mathrm{m}$-thick) slices were cut in $4^{\circ} \mathrm{C}$ oxygenated $\left(95 \% \mathrm{O}_{2}-5 \% \mathrm{CO}_{2}\right)$ slicing medium. The resulting slices were immediately transferred to a holding chamber, in which they remained submerged in oxygenated recording medium (ACSF) consisting of (in mM): $124 \mathrm{NaCl}, 3 \mathrm{KCl}, 1.25 \mathrm{NaH}_{2} \mathrm{PO}_{4}, 2 \mathrm{MgO}_{4}, 26 \mathrm{NaHCO}_{3}$, $2 \mathrm{CaCl}_{2}$, and 10 dextrose $(295-305 \mathrm{mOsm})$. Slices were held at $37^{\circ} \mathrm{C}$ for $45 \mathrm{~min}$ and then at room temperature. For each experiment, an individual slice was gently transferred to a submersion-type recording chamber, in which it was continuously perfused with oxygenated recording medium at room temperature.

Whole-cell recording. Whole-cell voltage-clamp pipette recordings were obtained from visually identified neurons using an infrared differential interference contrast (IR-DIC) video microscopy system (Stuart et al., 1993). Conventional whole-cell patch pipette recordings were obtained from identified neurons within $75 \mu \mathrm{m}$ of the slice surface. Patch electrodes (3-7 M $\Omega$ ) were pulled from $1.5 \mathrm{~mm}$ outer diameter borosilicate glass capillary tubing (World Precision Instruments, Sarasota, CA) using a micropipette puller (P-87; Sutter Instruments, Novato, CA), coated with Sylgard (Dow Corning, Midland, MI), and fire polished. Intracellular patch pipette solution for whole-cell recordings contained (in $\mathrm{mm}$ ): 120 Cs-gluconate, 10 HEPES, 11 EGTA, $11 \mathrm{CsCl}_{2}, 1 \mathrm{MgCl}_{2}, 1.25$ QX314, $2 \mathrm{Na}_{2}$-ATP, and 0.5 Na $-\mathrm{GTP}, \mathrm{pH} 7.25$ (285-290 mOsm). To isolate GABAergic synaptic currents, slices were perfused with ACSF containing $20 \mu \mathrm{M}$ 6-ciano-7-dinitroquinoxaline-2,3-dione (CNQX) and $50 \mu \mathrm{M}$ D-(-)-2-amino-5-phosphonovaleric acid (D-APV). Both, spontaneous (sIPSCs) and evoked (eIPSCs) IPSCs were recorded at the reversal potential for glutamatergic currents (holding potential, $0 \mathrm{mV}$; room temperature) at which IPSC events exhibit a large-amplitude and prominent decay (Otis et al., 1992). IPSCs were recorded on "agedmatched" heterotopic and normotopic pyramidal or interneurons (MAM) either in the same slice or in a different one, and CA1 pyramidal cells or layer II/III cortical supragranular neurons (control). Agematched refers to slices obtained from neonatal rat pups within an $11 \mathrm{~d}$ time period. eIPSCs were evoked at $0.1 \mathrm{~Hz}$ using a monopolar electrode placed in sites adjacent to the heterotopia or in the Schaffer collaterals. Low-frequency $(0.1 \mathrm{~Hz}), 100 \mu \mathrm{sec}$ pulses were applied and their intensity increased until threshold was reached for eliciting a detectable monosynaptic eIPSC. Stimulus intensity was then increased to two times threshold and was maintained at this intensity for the entire experiment. The peak of the evoked response was examined (at a fast time resolution) to ensure that the measured response, a delay $>5 \mathrm{msec}$, did not arise from the shock artifact. Voltage and current were recorded with an Axopatch 1D amplifier (Axon Instruments, Foster City, CA) and monitored on an oscilloscope. Whole-cell voltage-clamp data were low-pass filtered at 1 $\mathrm{kHz}(-3 \mathrm{~dB}$, eight-pole Bessel), digitally sampled at $10 \mathrm{kHz}$, and monitored with pClamp software (Axon Instruments) running on a personal Pentium computer (Dell Computer Company, Round Rock, TX). Whole-cell access resistance was carefully monitored throughout the recording, and cells were rejected if values changed by $>25 \%$ (or exceeded $20 \mathrm{M} \Omega$ ); only recordings with stable series resistance of $<20 \mathrm{M} \Omega$ were used for IPSC analysis.

In some voltage-clamp experiments, pharmacological agents were added to the perfusion medium: bicuculline methiodide (BMI) $(10 \mu \mathrm{M})$, carbachol $(5 \mu \mathrm{M})$, NO-711 $(50 \mu \mathrm{M})$, and GABA $(5 \mathrm{mM})$ were purchased from Sigma (St. Louis, MO); tiagabine $(20 \mu \mathrm{M})$ was a kind gift from Cephalon (West Chester, PA). Drugs were bath applied via the perfusate. A picospritzer (Parker Hannifin, Cleveland, $\mathrm{OH}$ ) was used for focal GABA application; a patch pipette was placed within $\sim 25 \mu \mathrm{m}$ of the cell soma (or $\sim 100 \mu \mathrm{m}$ of the cell dendrite) under IR-DIC, and brief pressure pulses $(10 \mathrm{msec})$ were used to eject GABA from the pipette tip.

Immunocytochemistry. To obtain hippocampal sections, rat brains were removed from animals perfused with $4 \%$ paraformaldehyde, cryoprotected (in 30\% sucrose solution), and frozen rapidly on dry ice, and $60-\mu \mathrm{m}$-thick floating sections were cut using a microtome (Leica). Sections were pretreated with $1.5 \% \mathrm{H}_{2} \mathrm{O}_{2}$ in PBS to reduce background from endogenous peroxidase activity. This was followed by several PBS and PBT $(1 \times$ PBS with $0.1 \%$ Triton X-100) washes. Tissue was blocked in $10 \%$ fetal bovine serum in PBT for $1 \mathrm{hr}$ and then incubated in the primary antibody [rabbit anti-GAT-1, GAT-2, and GAT-3; polyclonal antibody; Chemicon, Temecula, CA) diluted 1:500 in the blocking solution at $4^{\circ} \mathrm{C}$ for $48 \mathrm{hr}$. After washing in PBT for 40 min (five changes), the sections were incubated overnight at $4^{\circ} \mathrm{C}$ in biotinylated goat anti-rabbit IgG diluted 1:1000 in blocking solution. Another 90 min of PBT washes (four changes) was followed by incubation in the ABC complex (1:500 dilution of $\mathrm{A}$ and $\mathrm{B}$ reagents) from the Vectastain $\mathrm{ABC}$ kit (Vector Laboratories, Burlingame, CA) for $2 \mathrm{hr}$ at room temperature. Sections were washed for $50 \mathrm{~min}$ (five changes) in PBT. The colorimetric reaction was initiated by adding DAB substrate $(0.5 \mathrm{mg} / \mathrm{ml} 3,3$-diaminobenzidine and $0.005 \% \mathrm{H}_{2} \mathrm{O}_{2}$ in PBS). Sections were mounted on glass slides and allowed to air dry overnight. The tissue was dehydrated in EtOH (in increasing concentrations from 75 to $100 \%$ ) and xylene and mounted with Permount (Fisher Scientific, Houston, TX). All tissue sections were handled and processed in an identical manner.

Data analysis. Spontaneous IPSCs were measured using Mini Analysis 5.2.5 software (Synaptosoft, Decatur, GA). Each event was manually selected based on rise time, amplitude, and decay properties. Between 100 and 200 individual events were analyzed for each cell. Evoked IPSCs and GABA-evoked voltage-clamp responses were analyzed using Clampfit (Axon Instruments). Kinetic analysis of the IPSCs was performed with a single-exponential function. Results are presented as mean \pm SEM. Data before and after drug application were analyzed using a Student's $t$ test on the SigmaStat program (Jandel Scientific, Corte Madera, CA). To compare the results between different cell types, we used a one-way ANOVA. Significance level was taken as $p<0.05$.

\section{RESULTS}

Histological abnormalities observed in MAM-exposed rats have been described in detail previously (Singh, 1977; Chevassus-auLouis, 1998b; Colacitti et al., 1999; Baraban et al., 2000). All hippocampal slices used in the present study contained distinct clusters of displaced neurons (heterotopia) and loss of lamination (Fig. 1A). Neurons were selected for whole-cell voltage-clamp studies based on their location and morphology under direct IR-DIC visualization (Fig. $1 B, C$ ). Experimental data were obtained from hippocampal heterotopic pyramidal neurons (MAM). For comparison, control data were obtained from normotopic pyramidal neurons (e.g., pyramidal cells located within the normal CA1 laminar) and stratum radiatum interneurons (MAM), CA1 pyramidal neurons (control), and layer II/III supragranular neurons in cortical slices (control); these latter cells were chosen because they exhibit a molecular phenotype similar to heterotopic pyramidal neurons (Castro et al., 2002).

\section{Inhibitory GABAergic synaptic currents}

Altered GABA-mediated synaptic inhibition is a common feature in animal models of temporal lobe and malformation-associated epilepsy (Sloviter, 1991; Mangan and Lothman, 1996; Prince and Jacobs, 1998; Zhu and Roper, 2000; Coulter, 2001). To investigate GABAergic function at heterotopic synapses, whole-cell IPSCs were obtained from visually identified neurons in hippocampal slices from age-matched MAM-exposed and control rats. Monosynaptic eIPSCs were elicited in bathing medium supplemented with excitatory amino acid receptor blockers (50 $\mu \mathrm{M}$ D-APV and $20 \mu \mathrm{M}$ CNQX). For each cell, stimulus amplitudes were increased in intensity until a maximum response was obtained. In some experiments, $10 \mu \mathrm{M}$ BMI was added to the bathing medium, completely inhibiting the eIPSC $(n=45)$ and 

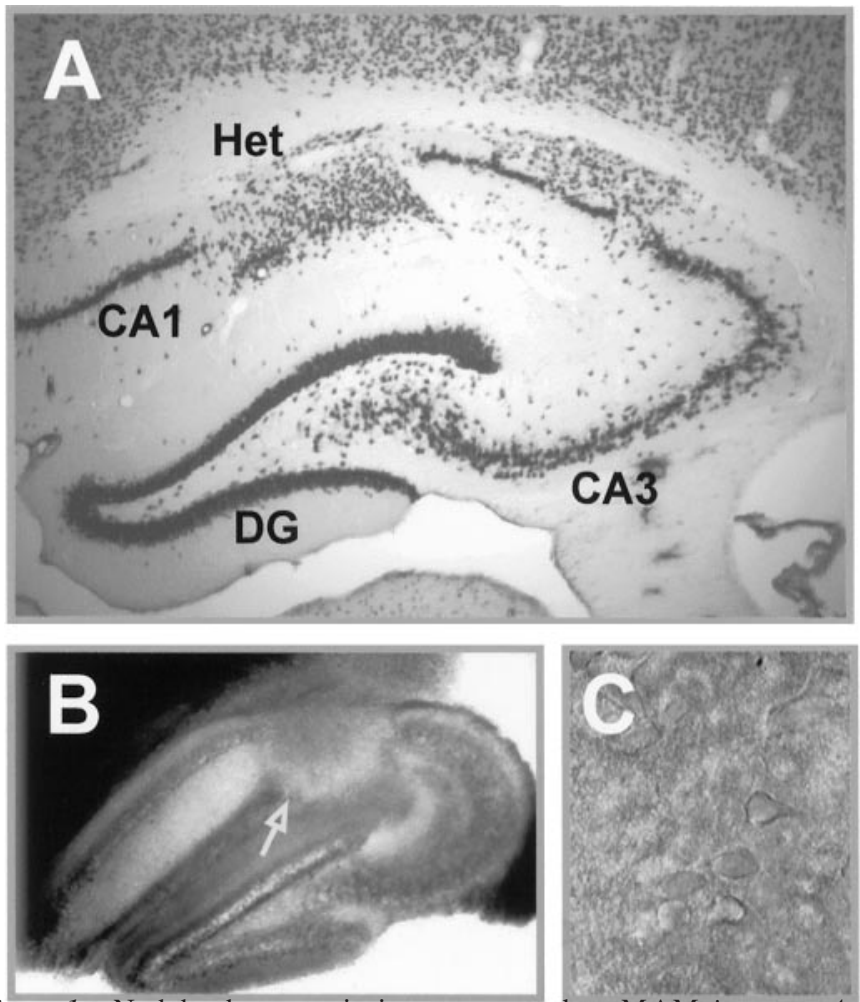

Figure 1. Nodular heterotopia in rats exposed to MAM in utero. A, Coronal hippocampal tissue section stained with the neuron-specific antibody neuronal-specific nuclear protein (Mullen et al., 1992). Note the presence of a cluster of displaced, pyramidal-like neurons in stratum CA1 pyramidale. $B$, Frame-grabber image of an acute hippocampal slice (300 $\mu \mathrm{m})$ under direct IR-DIC visualization $(10 \times)$. A nodular heterotopia in CA1 is indicated by the arrow. $C$, IR-DIC image of displaced, pyramidallike neurons at higher magnification $(40 \times)$. CA1, Stratum CA1 pyramidale; $C A 3$, stratum CA3 pyramidale; $D G$, dentate gyrus; Het, nodular heterotopia.

verifying the involvement of $\mathrm{GABA}_{\mathrm{A}}$ receptors. At a holding potential of $0 \mathrm{mV}$, evoked IPSCs displayed a fast-onset outward current with a small delay $(5-7 \mathrm{msec})$ after the stimulation for all cell types (Fig. 2). Representative examples of averaged eIPSC responses from CA1 pyramidal, normotopic pyramidal, and heterotopic pyramidal interneurons and layer II/III supragranular neurons are shown in Figure $2 A$. Analysis of eIPSCs revealed a significantly longer decay time for heterotopic pyramidal neurons (MAM) compared with all other cell types (ANOVA; $p<0.05$ ) (Fig. 2A-C).

Next we examined the kinetic properties of sIPSCs for each cell type recorded in the presence of $50 \mu \mathrm{M}$ D-APV and $20 \mu \mathrm{M}$ CNQX; addition of $10 \mu \mathrm{M}$ BMI to the bathing medium abolished sIPSCs $(n=45)$. Similar to evoked IPSCs, GABAergic spontaneous IPSCs recorded from hippocampal heterotopic neurons decayed significantly more slowly than sIPSCs recorded on all other cell types (ANOVA; $p<0.05$ ) (Fig. 3A,B). Whereas the rate of rise appears to be less dependent on voltage, decay time constants for individual IPSCs vary as a function of membrane voltage (Otis et al., 1992). In some cells, sIPSCs $(n=6)$ were recorded at different holding membrane potentials $(-80,-40$, and $-20 \mathrm{mV}$ ), and we found that decay time constants for hippocampal heterotopic cells remained slower than those measured on normotopic and control CA1 cells (data not shown). For
IPSC analysis, experiments were routinely performed at $0 \mathrm{mV}$, e.g., the reversal potential for glutamatergic currents, to ensure that we could obtain large and easily resolvable IPSC events for analysis. Although the decay curves of a small fraction of sIPSCs could be fit by double-exponential functions, following the examples of DeFazio and Hablitz (1998) or Taketo and Yoshioka (2000), all decay constants were expediently analyzed using single-exponential functions. Representative individual sIPSCs for each cell type are shown for direct comparison in Figure $3 A$. The measured peak amplitude and $10-90 \%$ rise time of spontaneous IPSCs showed no significant differences among cells (Fig. $3 C, D)$. To further illustrate the difference in sIPSC decay times, event histograms (Fig. 3E) were constructed from 100 individual sIPSCs recorded on a CA1 pyramidal neuron (control; P17) and an age-matched heterotopic pyramidal neuron (MAM; P17). Note the shift toward longer decay time constants for the heterotopic neuron. In a small number of experiments, tetrodotoxin (1 $\mu \mathrm{M})$ was added to the bathing medium to isolate miniature IPSCs. Consistent with our sIPSC findings, mIPSCs recorded on heterotopic pyramidal neurons were also characterized by a prolonged decay time constant (control CA1, $5.6 \pm 0.1 \mathrm{msec}, n=11$; MAM normotopic, $5.3 \pm 0.2 \mathrm{msec}, n=11$; MAM heterotopic, $10.6 \pm 0.3 \mathrm{msec}, n=11$; ANOVA; $p<0.001)$. Similar to a recent study using the irradiation model of cortical dysplasia indicating a decrease in IPSC frequency (Zhu and Roper, 2000), spontaneous and miniature IPSC frequencies were observed to be significantly lower for heterotopic cells (sIPSC, $1.00 \pm 0.14 \mathrm{~Hz}$; mIPSC, $0.34 \pm 0.04 \mathrm{~Hz}$; ANOVA; $p<0.001)$ compared with age-matched CA1 pyramidal (sIPSC, $2.02 \pm 0.37 \mathrm{~Hz}$; mIPSC, $0.88 \pm 0.04 \mathrm{~Hz}$ ) or normotopic pyramidal (sIPSC, $2.21 \pm 0.24 \mathrm{~Hz}$; mIPSC, $0.87 \pm$ $0.16 \mathrm{~Hz}$ ) cells; however, in contrast to the irradiation model, IPSC amplitudes were not increased in the MAM model (Fig. $3 C$ ), and no change in interneuron density has been observed (Baraban et al., 2000). Together, our data demonstrating that IPSCs (evoked or spontaneous) onto heterotopic neurons exhibit a dramatically prolonged decay phase suggests enhanced GABAergic inhibitory action at these synapses.

\section{Responses to exogenously applied GABA}

Altered postsynaptic GABA receptor expression or density can result in prolonged inhibitory synaptic currents and has been observed in several animal models of epilepsy (Rice et al., 1996; Brooks-Kayal et al., 1998; Molnar et al., 2000; Coulter, 2001), as well as tissue excised from temporal lobe epilepsy patients (Williamson et al., 1995; Loup et al., 2000). To determine whether inhibitory postsynaptic receptor function was altered, we tested the response of individual neurons to focally applied GABA. Somatic application of GABA (5 mM) onto CA1 pyramidal neurons voltage clamped at $0 \mathrm{mV}$ elicited a large outward current with a rapid rise time (Fig. $4 A, C$ ). A smaller outward current with a slower rise time could be evoked by focal application at the dendrite ( $\sim 100 \mu \mathrm{m}$ from the cell soma) (Fig. $4 A, B)$. No differences in amplitude or rise time were observed when comparing GABA-evoked current responses from CA1 pyramidal neurons with those from normotopic or heterotopic pyramidal neurons (ANOVA; $p>0.05$ ) (Fig. 4A-C). Coapplication of $10 \mu \mathrm{M} \mathrm{BMI}$ in the perfusion medium completely blocked GABA responses, indicating the involvement of a $\mathrm{GABA}_{\mathrm{A}}$ receptor (data not shown). Together, these studies demonstrating similar postsynaptic 

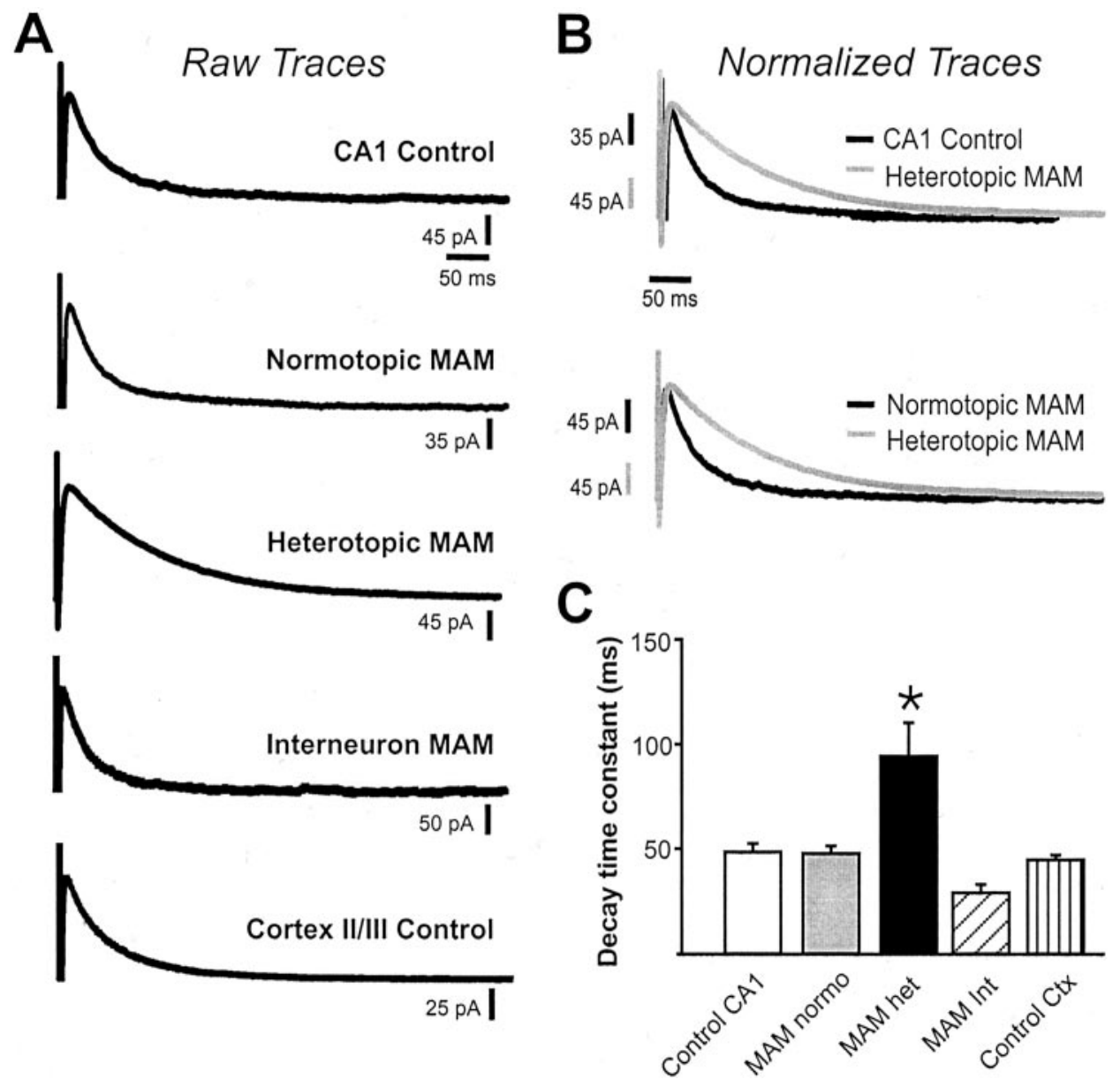

Figure 2. Evoked IPSCs. $A$, Representative eIPSC recordings obtained in hippocampal slices from control animals (CA1 pyramidal and layer II/III supragranular neocortex) and MAM-exposed rats (normotopic, heterotopic, and interneuron). Each trace is an average of six sweeps. $B$, Normalized traces comparing a heterotopic neuron with a CA1 control cell (top) and a normotopic pyramidal cell (bottom). Note that the decay of the evoked IPSC is significantly prolonged for heterotopic pyramidal neurons compared with the two other cell types. $C$, Plot of the decay time constant for all cells. Data are presented as the mean $\pm \mathrm{SEM} ;{ }^{*} p<0.001$ using a one-way ANOVA. Each bar represents 5-13 cells. normo, Normotopic; het; heterotopic; Int, interneuron; Ctx, cortex.

responses to exogenously applied GABA do not provideevidence supporting a hypothesis of altered postsynaptic $\mathrm{GABA}_{\mathrm{A}}$ receptor function at heterotopic synapses.

\section{Evidence for dysfunctional GABA transport}

The results thus far suggest prolonged GABAergic inhibition at heterotopic synapses. If the long IPSCs observed resulted from altered GABA transport and reuptake, we would predict (1) an increase in the duration of spontaneous or evoked GABA responses (Figs. 2, 3) and (2) prolongation of GABA responses in control cells during blockade of GATs with no change in GABA responses for heterotopic neurons using a GAT inhibitor. To test the latter hypothesis, we examined the kinetic properties of evoked IPSCs in the presence of tiagabine (electrogenic GAT inhibitor) (Braestrup et al., 1990) and NO-711 (a selective GAT-1 inhibitor) (Borden et al., 1994). Bath application of tiagabine (20 $\mu \mathrm{M})$ had no effect on the decay time constant for eIPSCs recorded on heterotopic neurons in slices from MAM-exposed rats (ANOVA; $p>0.2$ ). In contrast, tiagabine produced a significant prolongation of the decay time constant for eIPSCs recorded on CA1 pyramidal cells (control) and normotopic pyramidal cells (MAM) (ANOVA; $p<0.05$ ) (Fig. 5A). Experiments performed with the GAT-1 specific inhibitor NO-711 produced similar results (Fig. 5B). We also examined the kinetic properties of spontaneous IPSCs in the presence of NO-711. Similarly, bath application of NO-711 $(50 \mu \mathrm{M})$ had no effect on the decay time constant for sIPSCs recorded on heterotopic neurons (ANOVA; $p>0.9$ ) but produced a significant prolongation of the decay time constant for sIPSCs recorded on CA1 pyramidal cells (control) and normotopic pyramidal cells (MAM) (ANOVA; $p<0.05$ ). These findings suggest that altered GABA reuptake plays a role in the prolongation of IPSCs observed at heterotopic synapses.

In an additional set of experiments, we further analyzed the responses to focally applied GABA at baseline and after coapplication of GAT inhibitors. Closer examination of GABAevoked responses after a $10 \mathrm{msec}$ pulse at the cell soma of all heterotopic neurons revealed a long-lasting (16-24 sec) "late" outward current (Fig. 6A). This late GABA-evoked current was not observed on CA1 pyramidal or normotopic pyramidal neurons under baseline recording conditions. Consistent with previous findings (Fig. 4C), analysis of the early GABA response did not show any significant differences in parameters such as halfwidth or decay time constant (Fig. 6B). If there is no alteration in postsynaptic GABA receptor function on heterotopic neurons, then we hypothesize that this late response is attributable to decreased GABA reuptake mediated by a GABA transporter. To test this possibility, somatic application of GABA on normotopic CA1 pyramidal cells (MAM) and control CA1 pyramidal cells was performed in the presence of NO-711. In both cases, a long-lasting (late) outward current was elicited when GABA was focally applied at the cell soma in the presence of a GAT-1 inhibitor (Fig. 6D). Because pharmacological inhibition of GABA transport results in inhibitory responses on normal pyramidal cells that are nearly identical to those obtained on heterotopic cells under baseline recording conditions (Fig. 6, compare $A, D$ ), we conclude that a GAT defect underlies the prolonged GABAergic synaptic current observed at heterotopic synapses. 
A
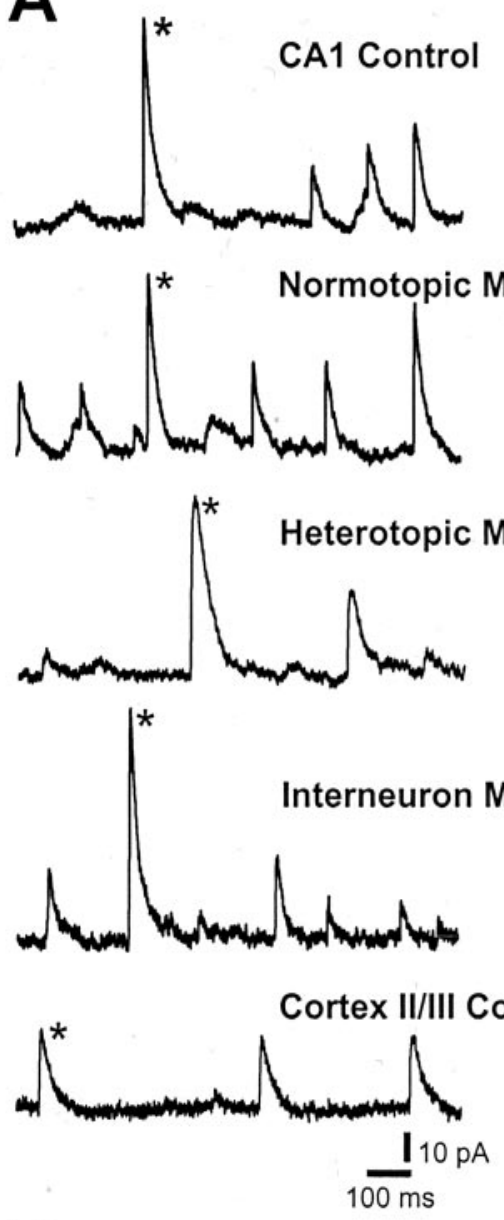

E
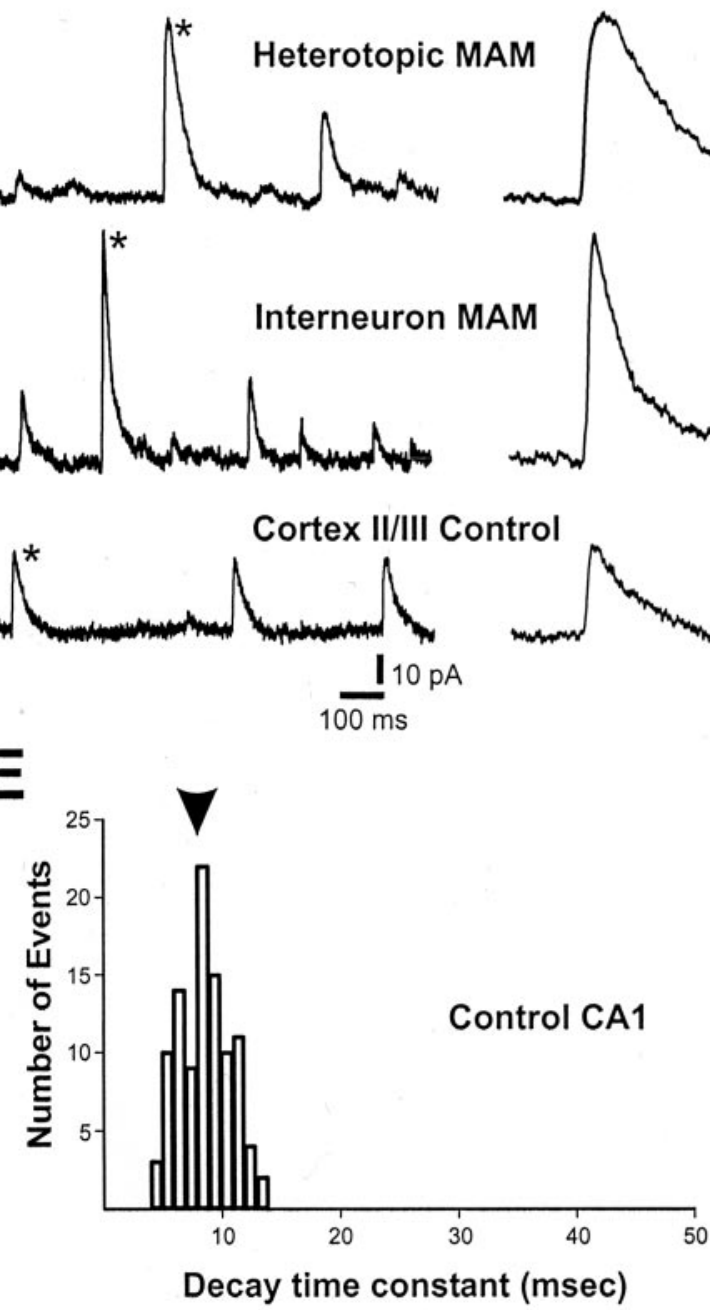

B
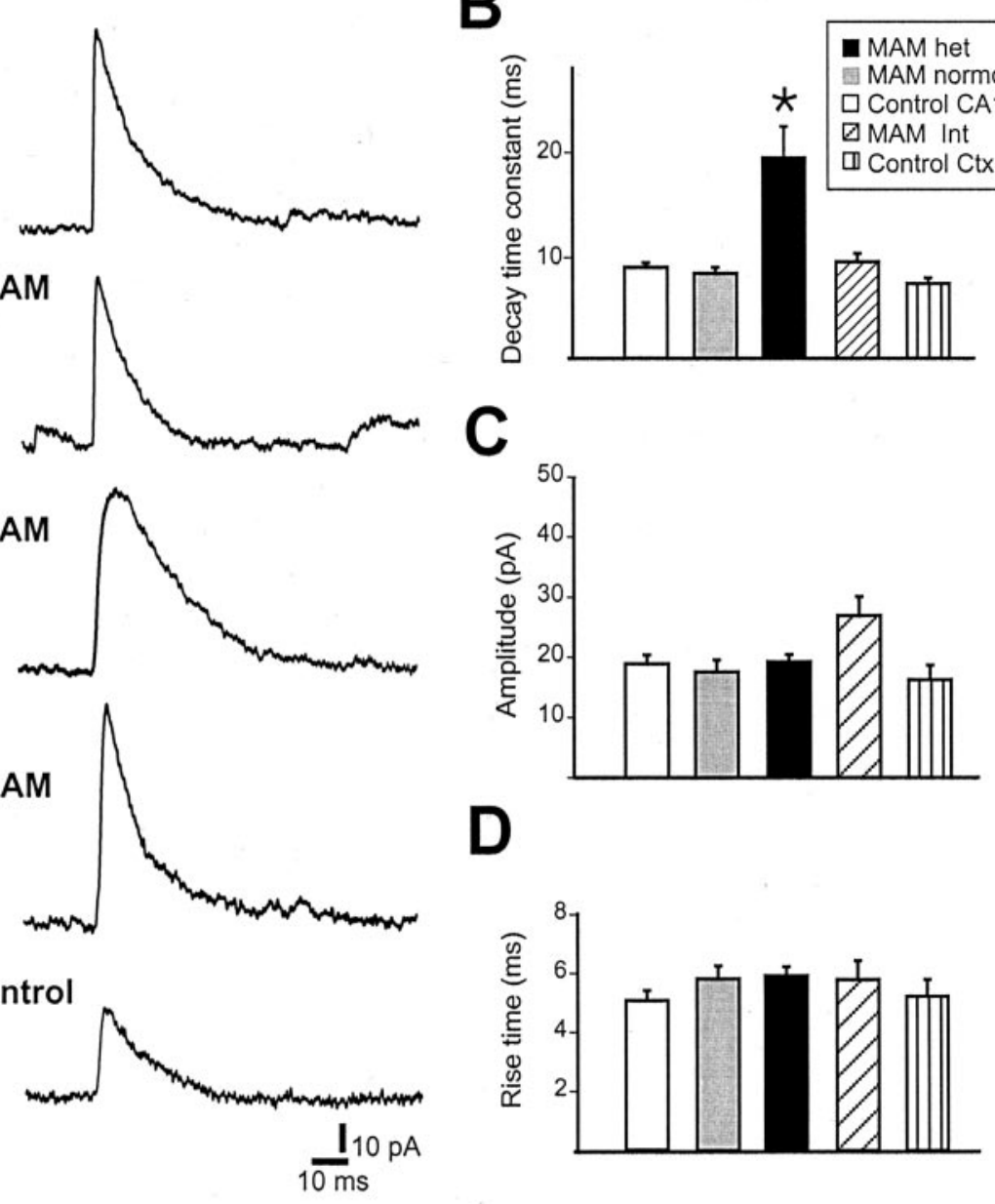

D

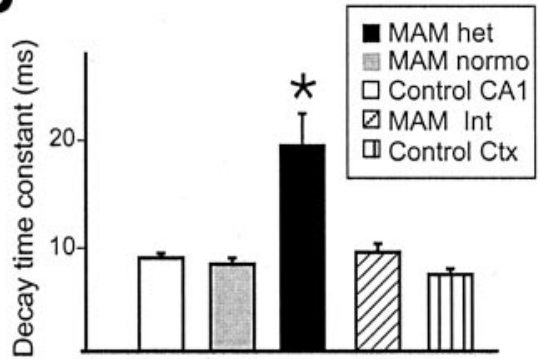

C

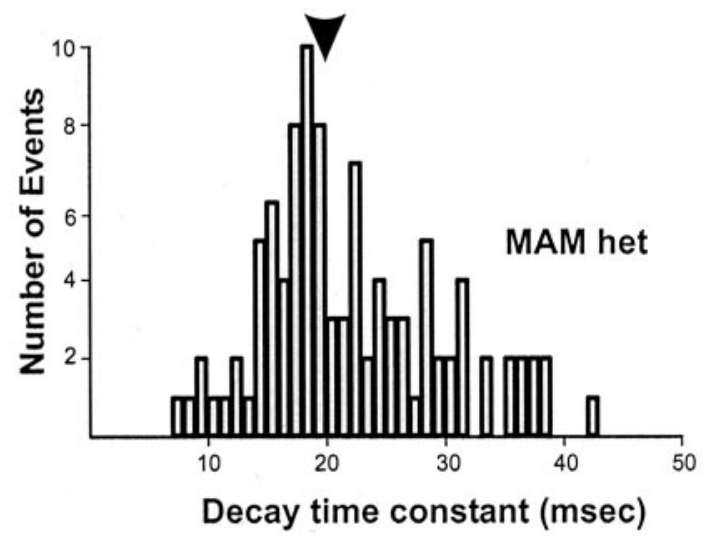

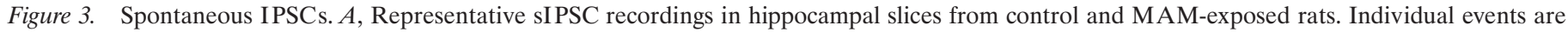

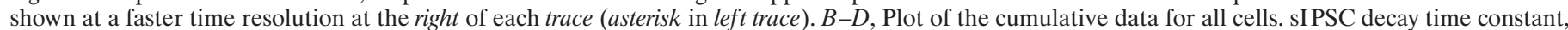

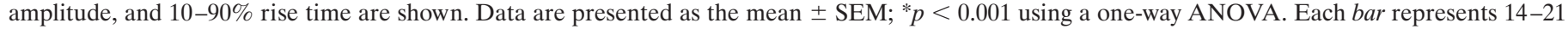

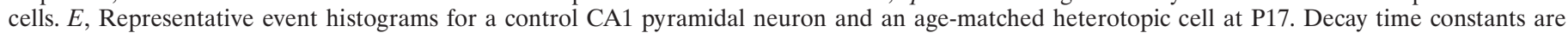

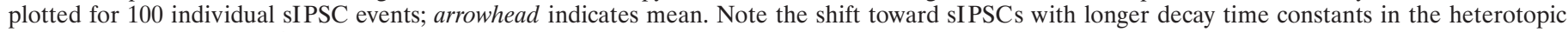
cell. normo, Normotopic; het; heterotopic; Int, interneuron; Ctx, cortex.

\section{Expression of GABA transporters}

GABA plasma membrane transporters influence synaptic transmission by removing GABA from the extracellular space (Soudijn and van Wijngaarden, 2000). To explore the expression and distribution patterns of GABA transporters in the dysplastic MAM brain, immunohistochemical studies using antibodies to
GAT-1, GAT-2, and GAT-3 were performed. In tissue sections from control rats, immunolabeling for GAT-1 was found throughout the hippocampal formation with strong immunoreactivity in a fine reticular network pattern around the neuropil, as reported previously (Ribak et al., 1996). In particular, somata of unlabeled principal neurons and pyramidal and granule cells were distinctly 
A

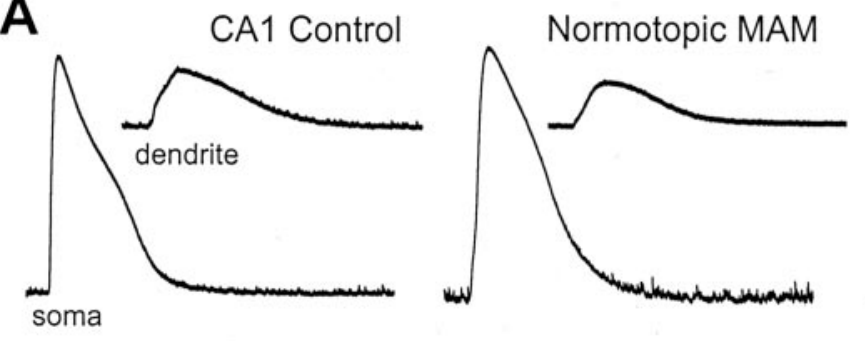

B

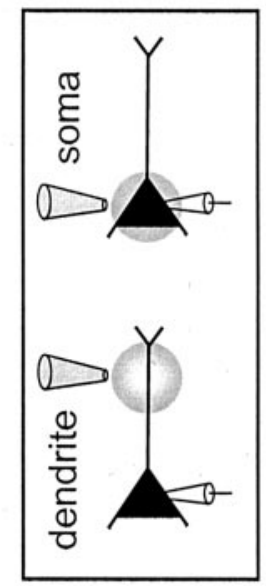

\section{C}
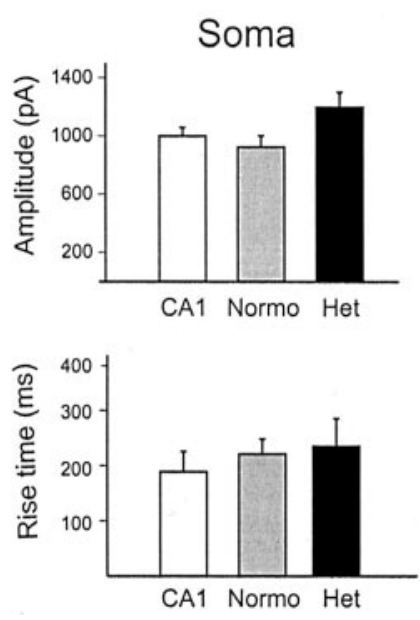
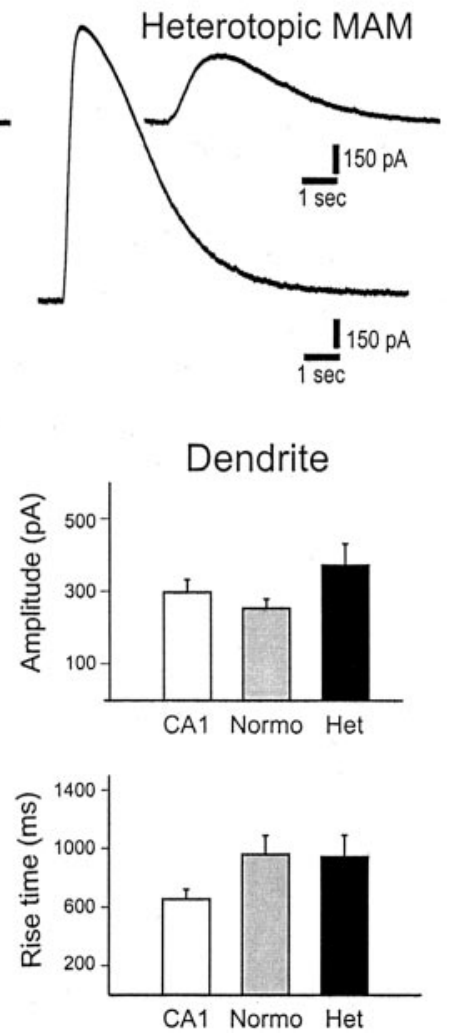

Figure 4. GABA responses in control and heterotopic neurons. $A$, Representative traces of responses to picospritzer GABA application at the cell soma (soma) or cell dendrite (dendrite) at a concentration of $5 \mathrm{~mm}$ illustrating the similarity in evoked responses between different cell types. $B$, Schematic of the recording configuration and picospritzer location. $C$, Plots of the somatic and dendritic response to local GABA application; GABAevoked current amplitude and $10-90 \%$ rise time are plotted. Data are presented as mean $\pm \mathrm{SEM}$; each bar represents five cells. Normo, Normotopic; het; heterotopic.

outlined by GAT-1-labeled puncta (Fig. 7A1,A2). A similar immunolabeling pattern was observed around normotopic CA1 and granule cells in tissue sections from MAM-exposed rats. However, GAT-1 staining appeared more diffuse in the MAMexposed animals, with a less prominent somatic staining pattern in regions containing heterotopic neurons (Fig. 7B1,B2). Dense GAT-3 immunoreactivity, with prominent puncta around principal cells, was also observed in hippocampal tissue sections from control rats (Fig. 7C). Similarly, but perhaps not as dramatically as for GAT-1, GAT-3 immunolabeling was diff use in heterotopic cell regions of hippocampal sections from MAM-exposed rats. GAT-3 immunolabeling around normotopic principal cells was prominent (Fig. 7D). GAT-2 was not prominently expressed in hippocampal tissue sections from control or MAM rat brains (data not shown), suggesting that this is not a major GABA transporter in the hippocampus, as reported previously (Durkin et al., 1995). The localization of GAT-1 and GAT-3 in the hippocampal formation is consistent with a role for these transporters in reuptake of GABA from the synaptic cleft, and our finding of diff use GAT immunolabeling (specifically, GAT-1) in heterotopic cell regions provides a structural correlate to the prolonged IPSC decay kinetics and GABA transporter pharmacology defects observed at heterotopic synapses.

\section{DISCUSSION}

Since the observation that malformed brain structure is associated with intractable forms of epilepsy, there has been a great deal of interest in trying to understand the function of dysplastic neurons. Here we performed experiments to investigate the influence of GABAergic inhibition on hippocampal heterotopic neurons in an animal model of malformation-associated epilepsy, e.g., rats exposed to MAM in utero. Our main findings in these animals include the following: (1) an alteration in the decay kinetics of evoked and spontaneous IPSCs recorded on heterotopic neurons, (2) "normal" inhibitory responses for heterotopic neurons after exogenous GABA application, (3) an inability to alter IPSC decay kinetics when heterotopic neurons are exposed to GABA transport inhibitors, and (4) a low level of GAT expression in heterotopic cell regions. Together, these results suggest altered inhibitory synaptic function at heterotopic synapses in the MAM model.

Abnormal electrical discharges, the hallmark of epilepsy, can result from an imbalance between excitation and inhibition. One mechanism to achieve this imbalance would be to alter inhibitory, GABA-mediated synaptic function. Although this idea has received widespread attention in the field of temporal lobe epilepsy (Williamson et al., 1995; Rice et al., 1996; Coulter, 2001), little systematic effort has been made to assess inhibitory synaptic function in malformation-associated epilepsy. Here we examined isolated IPSCs evoked by stimulation of GABAergic terminals or during spontaneous release of GABA contained in synaptic vesicles. These experiments used well characterized electrophysiological assays of GABAergic function, e.g., analysis of evoked and spontaneous IPSC kinetics (Otis and Mody, 1992; Roepstorff and Lambert, 1994; Salin and Prince, 1996; Jones and Westbrook, 1997). The main finding of our studies was that GABAergic IPSCs recorded on heterotopic neurons, in hippocampal slices from MAM-exposed rats, were marked by prolonged decay time constants. In the absence of altered IPSC amplitudes or rise times, these results can be interpreted as an increase in inhibition. In contrast to findings in other cortical malformation models (Prince et al., 1997; Rosen et al., 1998; Roper et al., 1999; Zhu and Roper, 2000), these alterations do not appear to be associated with a change in the number of GABAergic neurons in malformed cell regions (Colacitti et al., 1999; Baraban et al., 2000). 

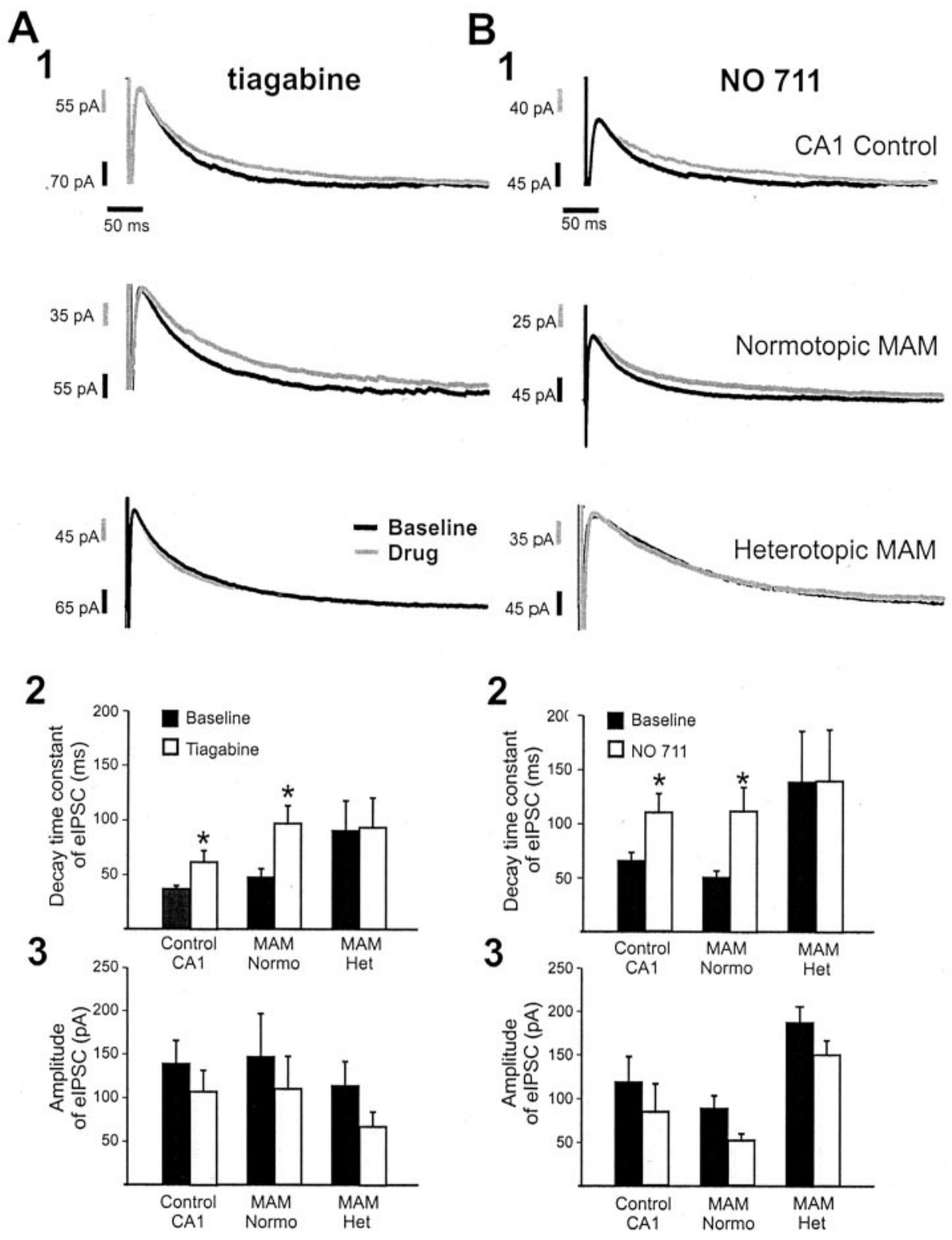

Figure 5. GABA transport inhibitors do not alter eIPSC responses on heterotopic neurons. $A$, Normalized traces of evoked IPSC responses before (Baseline) and $\sim 7 \mathrm{~min}$ after application of tiagabine $(A 1)$ or NO-711 (B2). Note the prolongation of eIPSC decay in the presence of a GABA transport inhibitor for CA1 control pyramidal and normotopic (Normo) neurons. These drugs did not alter the eIPSC recorded on heterotopic (Het) neurons. Cumulative data for all GABA transport inhibitor experiments are plotted for decay time constants ( $A 2$, tiagabine; $B 2, \mathrm{NO}-711)$ and eIPSC amplitudes ( $A 3$, tiagabine; $B 3$, NO-711). Data are presented as mean \pm SEM; each bar represents $8-16$ cells. ${ }^{*} p<0.001$ using a oneway ANOVA. The IPSC responses before and after the application of GABA transport inhibitor were scaled to the same peak amplitude (i.e., normalized).

Moreover, similar to observations made in human dysplastic tissue (Ferrer et al., 1994; Spreafico et al., 1998, 2000), it is likely that GABAergic innervation is increased (rather than decreased) in these heterotopic cell regions. Functional changes supporting an excitation-inhibition imbalance, i.e., a decrease in inhibitory synaptic function or a reduced number of GABAergic interneurons, are a common finding in several experimental and clinical epilepsy conditions (de Lanerolle et al., 1989; Marco et al., 1996; Buckmaster and Dudek, 1997; Gibbs et al., 1997; Brooks-Kayal et al., 1998; Hirsch et al., 1999) but were not observed here. As such, our findings do not support the hypothesis that excitationinhibition is altered in a manner supporting the generation of abnormal electrical discharges in the MAM model of cortical malformations. Moreover, our findings suggest a functional enhancement of GABAergic inhibitory action at heterotopic synapses that may serve to dampen the intrinsic hyperexcitability of heterotopic cells and suppress (rather than support) seizure activity.

Because changes in postsynaptic GABA receptor expression have been observed in temporal lobe epilepsy and could directly alter inhibitory current kinetics, we considered the possibility that a change in postsynaptic receptor function occurs. If we believe that altered postsynaptic GABA receptor function-expression contributes to the observed prolongation of decay time constants, then we would expect exogenous GABA application onto heterotopic cells to evoke inhibitory response that are larger than GABA-evoked responses on control neurons. In experiments using focal application of GABA, we failed to observe differences in the response of heterotopic neurons to these manipulations when comparing different groups of cells. For example, focal GABA application evoked similar current profiles for all cells tested. A more subtle alteration, such as a shift in the type of GABA receptor subunit expressed on heterotopic neurons (Brooks-Kayal et al., 1998; DeFazio and Hablitz, 1999) or altered $\mathrm{GABA}_{\mathrm{A}}$ receptor desensitization kinetics (Jones and Westbrook, 1995) are plausible alternative explanations for the slower decay time constants observed here and cannot be directly ruled out at this time. However, these alterations normally produce a modest 


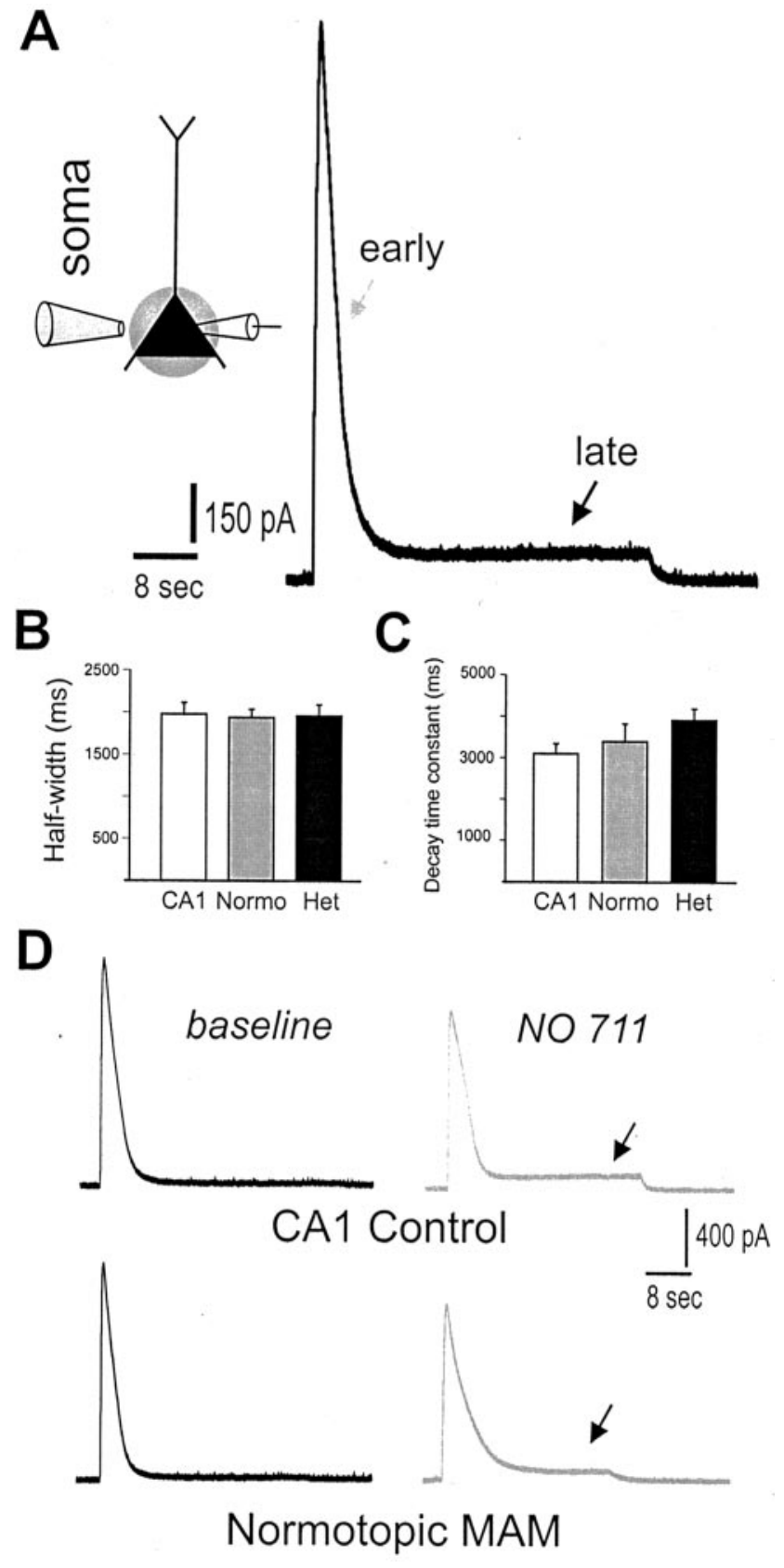

Figure 6. Local GABA applications in the presence of a GABA transport inhibitor. $A$, Representative trace from a heterotopic pyramidal neuron during somatic GABA application $(5 \mathrm{~mm})$. Note the presence of an outward current with early and late components. $B$, Plot of the half-width for GABA-evoked somatic currents. Data plotted represent the early outward current component. $C$, Plot of the decay time constant for GABA-evoked somatic currents. Data are presented as mean \pm SEM. $D$, Traces showing a GABA-evoked somatic current before (baseline) and $\sim 7$ min after bath application of NO-711. Note that a late outward current (arrow) appears during perfusion with the GABA transport inhibitor. Normo, Normotopic; Het, heterotopic.

change in decay kinetics and are unlikely to account for the nearly twofold change in decay time constants observed. Thus, at the present time, our results do not provide evidence suggesting a role for either enhanced presynaptic GABA release or impaired postsynaptic GABA receptor function in the MAM model.

Another explanation that could explain the prolonged GABA-
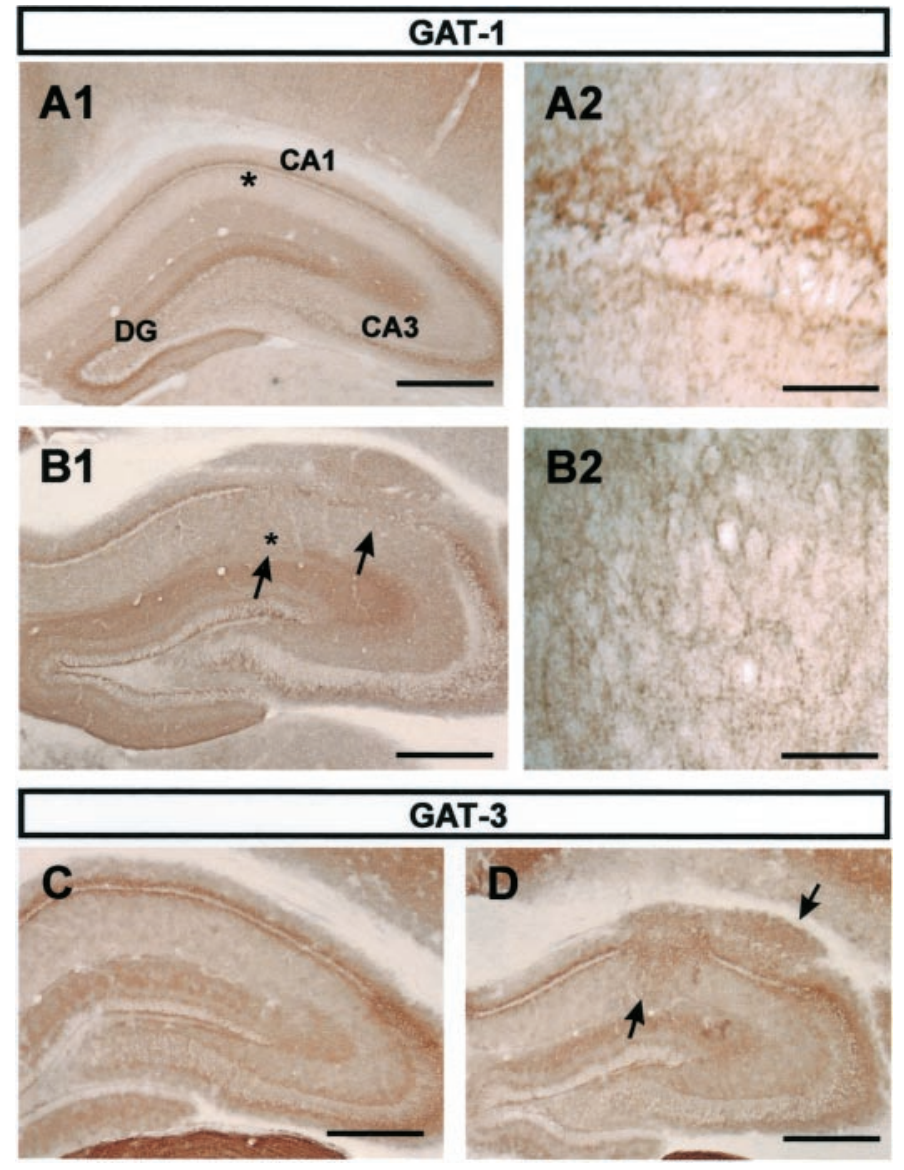

Figure 7. GABA transporter expression. A1, Coronal hippocampal section showing GAT-1 labeling around cell bodies in CA1-CA3 stratum pyramidale and granule cells of the dentate gyrus. This section is from a control, saline-treated rat. $A 2$, A close-up section of CA1 showing GAT-1 staining at higher resolution (location indicated by asterisk in $A 1$ ). B1, B2, GAT-1 labeling for a coronal hippocampal section from an MAMexposed rat at low (B1)- and high (B2)-power magnification. Note the diffuse GAT-1 labeling around cell bodies in the nodular heterotopia (arrows). $C, D$, Same for GAT-3. Magnification (Zeiss stereoscope): $A 1$, $B 1, C, D, 1.6 \times ; A 2, B 2,132 \times$. Scale bars: $A 1, B 1,600 \mu \mathrm{m} ; A 2, B 2,80 \mu \mathrm{m}$; $C, D, 500 \mu \mathrm{m}$. $C A 1$, Stratum CA1 pyramidale; $C A 3$, stratum CA3 pyramidale; $D G$, dentate gyrus.

ergic IPSCs observed at heterotopic synapses is an alteration of GABA transport-reuptake mechanisms in these dysplastic brain regions. If the kinetics of the GABA transporter are altered or a decrease in the expression of GABA transporters occurs, one would predict that GABA would remain in the synaptic cleft for a prolonged period, resulting in slow postsynaptic IPSC decay kinetics. At normal hippocampal synapses, evoked IPSC decay time constants become prolonged during application of a GABA reuptake blocker (Dingledine and Korn, 1985; Hablitz and Lebeda, 1985; Rekling et al., 1990; Thompson and Gahwiler, 1992). These findings suggest that removal of GABA by transporter reuptake systems plays a major role in the termination of a stimulus-evoked IPSC. In support of the hypothesis that GABA transporter function is altered at heterotopic synapses, we observed that GABA reuptake blockers (tiagabine and NO-711) prolonged the decay time constant of evoked IPSCs onto control cells but had no effect on heterotopic cells. Additional support for this hypothesis comes from our observation that "excessive" focal application of a saturating concentration of GABA (i.e., a condi- 
tion in which reuptake mechanisms play a major role in the clearance of transmitter) at heterotopic cell somata elicited a dual component response with the slow late response, suggestive of an inability to clear GABA from the synaptic cleft. These latter observations are further supported by experiments on control neurons wherein focal GABA application concomitant with bath application of a GABA transporter blocker elicited similar dual component responses. Finally, our electrophysiological observations were supported by immunohistochemical results indicating a diffuse (perhaps reduced level) of hippocampal GABA transporter expression in hippocampal heterotopia. For example, GAT-1 expression was barely detectable in heterotopic cell regions of MAM-exposed rats (Fig. 7). It is interesting to note that a change in the number and/or distribution of GABA transporters has been observed in the brains of kindled or pilocarpinetreated rats and in tissue from epileptic patients with cortical dysplasia (During et al., 1995; Hirao et al., 1998; Andre et al., 2001), although, in both examples, it was suggested that these changes contribute to a preservation of inhibitory tone (in response to a loss of interneurons) and an exacerbation of epileptiform activity (via decreased probability for GABA heterotransport). In contrast, our results are supportive of the hypothesis that a GABA reuptake deficiency in dysplastic cell regions contributes to the prolonged GABAergic IPSCs observed at heterotopic synapses and increases functional inhibition.

In conclusion, the results reported here suggest that prolonged GABA-evoked responses observed at heterotopic synapses are attributable, at least in part, to a change in the function-distribution of GABA transporters. In the presence of a functional alteration in GABA transport mechanisms, GABA remains in the synaptic cleft for a prolonged period in which it can influence the strength of both inhibitory and excitatory synaptic transmission (Isaacson et al., 1993; Soudijn and van Wijngaarden, 2000). It is therefore reasonable to interpret our findings as providing a mechanism to reduce the intrinsic hyperexcitability associated with a nodular heterotopia. Whether the observed alterations in GABA inhibition are the result of a neurodevelopmental abnormality induced by prenatal MAM exposure or represent some type of postnatal compensatory response is not known at this time. However, it is already well established that spontaneous seizure activity is not common in the MAM model of malformation-associated epilepsy (Baraban and Schwartzkroin, 1995; Germano et al., 1996; Baraban et al., 2000), and humans with cortical dysplasia do not always exhibit a severe epileptic phenotype (Andermann, 2000). Therefore, our findings provide a plausible explanation for these puzzling "seizure suppression" observations and offer additional insight into the function of a malformed brain.

\section{REFERENCES}

Amano S, Ihara N, Uemura S, Yokoyama M, Ikeda M, Serikawa T, Sasahara M, Kataoka H, Hayase Y, Hazama F (1996) Development of a novel rat mutant with spontaneous limbic-like seizures. Am J Pathol 149:329-336.

Andermann F (2000) Cortical dysplasias and epilepsy: a review of the architectonic, clinical, and seizure patterns. Adv Neurol 84:479-496.

Andre V, Marescaux C, Nehlig A, Fritschy JM (2001) Alterations of hippocampal GABAergic system contribute to development of spontaneous recurrent seizures in the rat lithium-pilocarpine model of temporal lobe epilepsy. Hippocampus 11:452-468.

Avoli M, Bernasconi A, Mattia D, Olivier A, Hwa GG (1999) Epileptiform discharges in the human dysplastic neocortex: in vitro physiology and pharmacology. Ann Neurol 46:816-826.

Baraban SC, Schwartzkroin PA (1995) Electrophysiology of CA1 pyramidal neurons in an animal model of neuronal migration disorders: prenatal methylazoxymethanol treatment. Epilepsy Res 22:145-156.
Baraban SC, Schwartzkroin PA (1996) Flurothyl seizure susceptibility in rats following prenatal methylazoxymethanol treatment. Epilepsy Res 23:189-194.

Baraban SC, Wenzel HJ, Hochman DW, Schwartzkroin PA (2000) Characterization of heterotopic cell clusters in the hippocampus of rats exposed to methylazoxymethanol in utero. Epilepsy Res 39:87-102.

Borden LA, Murali Dhar TG, Smith KE, Weinshank RL, Branchek TA, Gluchowski C (1994) Tiagabine, SK\&F 89976-A, CI-966, and NNC711 are selective for the cloned GABA transporter GAT-1. Eur J Pharmacol 269:219-224.

Braestrup C, Nielsen EB, Sonnewald U, Knutsen LJ, Andersen KE, Jansen JA, Frederiksen K, Andersen PH, Mortensen A, Suzdak PD (1990) (R)- $N$-[4, 4-bis(3-methyl-2-thienyl)but-3-en-1-yl]nipecotic acid binds with high affinity to the brain gamma-aminobutyric acid uptake carrier. J Neurochem 54:639-647.

Brooks-Kayal AR, Shumate MD, Jin H, Rikhter TY, Coulter DA (1998) Selective changes in single cell GABA(A) receptor subunit expression and function in temporal lobe epilepsy. Nat Med 4:1166-1172.

Buckmaster PS, Dudek FE (1997) Neuron loss, granule cell axon reorganization, and functional changes in the dentate gyrus of epileptic kainate-treated rats. J Comp Neurol 385:385-404.

Castro PA, Cooper EC, Lowenstein DH, Baraban SC (2001) Hippocampal heterotopia lack functional Kv4.2 potassium channels in the methylazoxymethanol model of cortical malformations and epilepsy. J Neurosci 21:6626-6634.

Castro PA, Pleasure SJ, Baraban SC (2002) Hippocampal heterotopia with molecular and electrophysiological properties of neocortical neurons. Neuroscience, in press.

Chan S, Chin SS, Nordli DR, Goodman RR, DeLaPaz RL, Pedley TA (1998) Prospective magnetic resonance imaging identification of focal cortical dysplasia, including the non-balloon cell subtype. Ann Neurol 44:749-757.

Chevassus-au-Louis N, Ben-Ari Y, Vergnes M (1998a) Decreased seizure threshold and more rapid rate of kindling in rats with cortical malformation induced by prenatal treatment with methylazoxymethanol. Brain Res 812:252-255.

Chevassus-au-Louis N, Rafiki A, Jorquera I, Ben-Ari Y, Represa A (1998b) Neocortex in the hippocampus: an anatomical and functional study of CA1 heterotopias after prenatal treatment with methylazoxymethanol in rats. J Comp Neurol 394:520-536.

Colacitti C, Sancini G, DeBiasi S, Franceschetti S, Caputi A, Frassoni C Cattabeni F, Avanzini G, Spreafico R, Di Luca M, Battaglia G (1999) Prenatal methylazoxymethanol treatment in rats produces brain abnormalities with morphological similarities to human developmental brain dysgeneses. J Neuropathol Exp Neurol 58:92-106.

Coulter DA (2001) Epilepsy-associated plasticity in gamma-aminobutyric acid receptor expression, function, and inhibitory synaptic properties. Int Rev Neurobiol 45:237-252.

de Feo MR, Mecarelli O, Ricci GF (1995) Seizure susceptibility in immature rats with micrencephaly induced by prenatal exposure to methylazoxymethanol acetate. Pharmacol Res 31:109-114.

de Lanerolle NC, Kim JH, Robbins RJ, Spencer DD (1989) Hippocampal interneuron loss and plasticity in human temporal lobe epilepsy. Brain Res 495:387-395.

DeFazio RA, Hablitz JJ (1999) Reduction of zolpidem sensitivity in a freeze lesion model of neocortical dysgenesis. J Neurophysiol 81: 404-407.

Defazio T, Hablitz JJ (1998) Zinc and zolpidem modulate mIPSCs in rat neocortical pyramidal neurons. J Neurophysiol 80:1670-1677.

Dingledine R, Korn SJ (1985) $\gamma$-Aminobutyric acid uptake and the termination of inhibitory synaptic potentials in the rat hippocampal slice. J Physiol (Lond) 366:387-409.

During MJ, Ryder KM, Spencer DD (1995) Hippocampal GABA transporter function in temporal-lobe epilepsy. Nature 376:174-177.

Durkin MM, Smith KE, Borden LA, Weinshank RL, Branchek TA, Gustafson EL (1995) Localization of messenger RNAs encoding three GABA transporters in rat brain: an in situ hybridization study. Brain Res Mol Brain Res 33:7-21.

Ferrer I, Oliver B, Russi A, Casas R, Rivera R (1994) Parvalbumin and calbindin-D28k immunocytochemistry in human neocortical epileptic foci. J Neurol Sci 123:18-25.

Fleck MW, Hirotsune S, Gambello MJ, Phillips-Tansey E, Suares G, Mervis RF, Wynshaw-Boris A, McBain CJ (2000) Hippocampal abnormalities and enhanced excitability in a murine model of human lissencephaly. J Neurosci 20:2439-2450.

Germano IM, Z hang YF, Sperber EF, Moshe SL (1996) Neuronal migration disorders increase susceptibility to hyperthermia-induced seizures in developing rats. Epilepsia 37:902-910.

Gibbs JW, 3rd, Shumate MD, Coulter DA (1997) Differential epilepsyassociated alterations in postsynaptic GABA(A) receptor function in dentate granule and CA1 neurons. J Neurophysiol 77:1924-1938.

Hablitz JJ, Lebeda FJ (1985) Role of uptake in gamma-aminobutyric acid (GABA)-mediated responses in guinea pig hippocampal neurons. Cell Mol Neurobiol 5:353-371.

Hicks SP, D'Amato CJ, Lowe MJ (1959) The development of the mam- 
malian nervous system. I. Malformation of the brain, especially the cerebral cortex, induced in rats by radiation. II. Some mechanisms of the malformations of the cortex. J Comp Neurol 113:435-469.

Hirabayashi S, Binnie CD, Janota I, Polkey CE (1993) Surgical treatment of epilepsy due to cortical dysplasia: clinical and EEG findings. J Neurol Neurosurg Psychiatry 56:765-770.

Hirao T, Morimoto K, Yamamoto Y, Watanabe T, Sato H, Sato K, Sato S, Yamada N, Tanaka K, Suwaki H (1998) Time-dependent and regional expression of GABA transporter mRNAs following amygdalakindled seizures in rats. Brain Res Mol Brain Res 54:49-55.

Hirsch JC, Agassandian C, Merchan-Perez A, Ben-Ari Y, DeFelipe J, Esclapez M, Bernard C (1999) Deficit of quantal release of GABA in experimental models of temporal lobe epilepsy. Nat Neurosci 2: 499-500.

Houser CR (1990) Granule cell dispersion in the dentate gyrus of humans with temporal lobe epilepsy. Brain Res 535:195-204.

Issacson JS, Solis JM, Nicoll RA (1993) Local and diffuse synaptic actions of GABA in the hippocampus. Neuron 10:165-175.

Jones MV, Westbrook GL (1995) Desensitized states prolong GABAA channel responses to brief agonist pulses. Neuron 15:181-191.

Jones MV, Westbrook GL (1997) Shaping of IPSCs by endogenous calcineurin activity. J Neurosci 17:7626-7633.

Kuzniecky R (1988) Focal cortical dysplasia. J Neurosurg 69:478.

Lehericy S, Dormont D, Semah F, Clemenceau S, Granat O, Marsault C, Baulac M (1995) Developmental abnormalities of the medial temporal lobe in patients with temporal lobe epilepsy. Am J Neuroradiol 16:617-626.

Loup F, Wieser HG, Yonekawa Y, Aguzzi A, Fritschy JM (2000) Selective alterations in GABAA receptor subtypes in human temporal lobe epilepsy. J Neurosci 20:5401-5419.

Maehara T, Shimizu H, Yagishita A, Kaito N, Oda M, Arai N (1999) Interictal hyperperfusion observed in infants with cortical dysgenesis. Brain Dev 21:407-412.

Mangan PS, Lothman EW (1996) Profound disturbances of pre- and postsynaptic GABAB-receptor-mediated processes in region CA1 in a chronic model of temporal lobe epilepsy. J Neurophysiol 76:1282-1296.

Marco P, Sola RG, Pulido P, Alijarde MT, Sanchez A, Ramon y Cajal S, DeFelipe J (1996) Inhibitory neurons in the human epileptogenic temporal neocortex. An immunocytochemical study. Brain 119:1327-1347.

Mischel PS, Nguyen LP, Vinters HV (1995) Cerebral cortical dysplasia associated with pediatric epilepsy. Rev of neuropathologic features and proposal for a grading system. J Neuropathol Exp Neurol 54:137-153.

Molnar LR, Fleming WW, Taylor DA (2000) Alterations in neuronal gamma-aminobutyric acid(A) receptor responsiveness in genetic models of seizure susceptibility with different expression patterns. J Pharmacol Exp Ther 295:1258-1266.

Morioka T, Nishio S, Ishibashi H, Muraishi M, Hisada K, Shigeto H, Yamamoto T, Fukui M (1999) Intrinsic epileptogenicity of focal cortical dysplasia as revealed by magnetoencephalography and electrocorticography. Epilepsy Res 33:177-187.

Mullen RH, Buck CR, Smith AM (1992) NeuN, a neuronal specific nuclear protein in vertebrates. Development 116:201-211.

Ohtsuka Y, Sato M, Sanada S, Yoshinaga H, Oka E (2000) Suppressionburst patterns in intractable epilepsy with focal cortical dysplasia. Brain Dev 22:135-138.

Otis TS, Mody I (1992) Modulation of decay kinetics and frequency of GABAA receptor-mediated spontaneous inhibitory postsynaptic currents in hippocampal neurons. Neuroscience 49:13-32.

Palmini A, Andermann F, Olivier A, Tampieri D, Robitaille Y, Andermann E, Wright G (1991a) Focal neuronal migration disorders and intractable partial epilepsy: a study of 30 patients. Ann Neurol 30:741-749.

Palmini A, Andermann F, Olivier A, Tampieri D, Robitaille Y (1991b) Focal neuronal migration disorders and intractable partial epilepsy: results of surgical treatment. Ann Neurol 30:750-757.

Palmini A, Gambardella A, Andermann F, Dubeau F, da Costa JC, Olivier A, Tampieri D, Gloor P, Quesney F, Andermann E, Paglioli E, Paglioli-Neto E, Coutinho L, Lebanc R, Kim H-I (1995) Intrinsic epileptogenicity of human dysplastic cortex as suggested by corticography and surgical results. Ann Neurol 37:476-487.
Prince DA, Jacobs K (1998) Inhibitory function in two models of chronic epileptogenesis. Epilepsy Res 32:83-92.

Prince DA, Jacobs KM, Salin PA, Hoffman S, Parada I (1997) Chronic focal neocortical epileptogenesis: does disinhibition play a role? Can J Physiol Pharmacol 75:500-507.

Raymond AA, Fish DR, Stevens JM, Cook MJ, Sisodiya SM, Shorvon SD (1994) Association of hippocampal sclerosis with cortical dysgenesis in patients with epilepsy. Neurology 44:1841-1845.

Rekling JC, Jahnsen H, Mosfeldt Laursen A (1990) The effect of two lipophilic gamma-aminobutyric acid uptake blockers in CA1 of the rat hippocampal slice. Br J Pharmacol 99:103-106.

Ribak CE, Tong WM, Brecha NC (1996) GABA plasma membrane transporters, GAT-1 and GAT-3, display different distributions in the rat hippocampus. J Comp Neurol 367:595-606.

Rice A, Rafiq A, Shapiro SM, Jakoi ER, Coulter DA, DeLorenzo RJ (1996) Long-lasting reduction of inhibitory function and gammaaminobutyric acid type $A$ receptor subunit mRNA expression in a model of temporal lobe epilepsy. Proc Natl Acad Sci USA 93:96659669.

Roepstorff A, Lambert JD (1994) Factors contributing to the decay of the stimulus-evoked IPSC in rat hippocampal CA1 neurons. J Neurophysiol 72:2911-2926.

Roper SN, Eisenschenk S, King MA (1999) Reduced density of parvalbumin- and calbindin D28-immunoreactive neurons in experimental cortical dysplasia. Epilepsy Res 37:63-71.

Rosen GD, Jacobs KM, Prince DA (1998) Effects of neonatal freeze lesions on expression of parvalbumin in rat neocortex. Cereb Cortex 8:753-761.

Salin PA, Prince DA (1996) Spontaneous GABAA receptor-mediated inhibitory currents in adult rat somatosensory cortex. J Neurophysiol 75:1573-1588.

Sancini G, Franceschetti S, Battaglia G, Colacitti C, Di Luca M, Spreafico R, Avanzini G (1998) Dysplastic neocortex and subcortical heterotopias in methylazoxymethanol-treated rats: an intracellular study of identified pyramidal neurones. Neurosci Lett 246:181-185.

Schwartzkroin PA (1994) Role of the hippocampus in epilepsy. Hippocampus 4:239-242.

Singh SC (1977) Ectopic neurones in the hippocampus of the postnatal rat exposed to methylazoxymethanol during foetal development. Acta Neuropathol (Berl) 40:111-116.

Sloviter RS (1991) Permanently altered hippocampal structure, excitability, and inhibition after experimental status epilepticus in the rat: the "dormant basket cell" hypothesis and its possible relevance to temporal lobe epilepsy. Hippocampus 1:41-66.

Soudijn W, van Wijngaarden I (2000) The GABA transporter and its inhibitors. Curr Med Chem 7:1063-1079.

Spreafico R, Pasquier B, Minotti L, Garbelli R, Kahane P, Grand S, Benabid AL, Tassi L, Avanzini G, Battaglia G, Munari C (1998) Immunocytochemical investigation on dysplastic human tissue from epileptic patients. Epilepsy Res 32:34-48.

Spreafico R, Tassi L, Colombo N, Bramerio M, Galli C, Garbelli R, Ferrario A, Lo Russo G, Munari C (2000) Inhibitory circuits in human dysplastic tissue. Epilepsia 41:S168-S173.

Stuart GJ, Dodt HU, Sakmann B (1993) Patch-clamp recordings from the soma and dendrites of neurons in brain slices using infrared video microscopy. Pflügers Arch 423:511-518.

Taketo M, Yoshioka T (2000) Developmental change of GABA(A) receptor-mediated current in rat hippocampus. Neuroscience 96: 507-514.

Thompson SM, Gahwiler BH (1992) Effects of the GABA uptake inhibitor tiagabine on inhibitory synaptic potentials in rat hippocampal slice cultures. J Neurophysiol 67:1698-1701.

Wenzel HJ, Robbins CA, Tsai LH, Schwartzkroin PA (2001) Abnormal morphological and functional organization of the hippocampus in a p35 mutant model of cortical dysplasia associated with spontaneous seizures. J Neurosci 21:983-998.

Williamson A, Telfeian AE, Spencer DD (1995) Prolonged GABA responses in dentate granule cells in slices isolated from patients with temporal lobe sclerosis. J Neurophysiol 74:378-387.

Zhu WJ, Roper SN (2000) Reduced inhibition in an animal model of cortical dysplasia. J Neurosci 20:8925-8931. 